\title{
Nowe cele terapii ukierunkowanej w nowotworach układu chłonnego z perspektywy ostatnich 5 lat badań
}

\author{
New therapeutic targets in lymphoid malignancies \\ - 5-year research perspective \\ Przemysław Juszczyński \\ Pracownia Hematologii Doświadczalnej, Zakład Diagnostyki Hematologicznej, \\ Instytut Hematologii i Transfuzjologii, Warszawa
}

\begin{abstract}
Streszczenie
Badania translacyjne nad nowotworami uktadu chtonnego $w$ perspektywie ostatnich 5 lat byty wyjatkowo fascynujacym i owocnym okresem. Przyczynity sie do tego nowe możliwości technologiczne, rozwój mocy obliczeniowych i bioinformatyki, a także wspótpraca ośrodków akademickich $i$ przemystu. Z perspektywy 5 lat $i$ wplywu tych badań na praktyke kliniczna za szczególnie ważne należy uznać wyniki badań dotyczacych epigenetycznych mechanizmów regulacji funkcji genomu, badań nad rola receptora B-komórkowego oraz mechanizmów immunomodulacyjnych dotyczacych nowotworu. Te obszary badawcze doprowadzity do rejestracji nowych leków, a ich potencjat translacyjny będzie najprawdopodobniej dalej rozwijany w kolejnych latach.
\end{abstract}

Słowa kluczowe: nowotwory układu chłonnego, sygnał BCR, zmiany epigenetyczne, mikrośrodowisko, immunomodulacja, leczenie celowane

Hematologia 2015; 6, 1: 1-9

\begin{abstract}
Translational studies on lymphoid malignancies have been, over the last 5 years, particularly intriguing and productive/fruitful. New discoveries have been fuelled by new technological research platforms, increasing computational powers, advances in bioinformatics and increasing academic-biotech/pharmaceutical partnerships. In some cases, this has led to vital advances in clinical practice where discoveries in epigenetic mechanisms were particularly significant in the regulation of human genome function, B-cell receptor signalling and tumour-associated immune escape mechanisms. It is very likely that the translational potential of these findings will thus be further developed in the future.
\end{abstract}

Key words: lymphoid malignancies, BCR signaling, epigenetic modifications, microenvironment, innunomodulation, targeted therapy

Hematologia 2015; 6, 1: 1-9

Adres do korespondencji: Przemysław Juszczyński, Pracownia Hematologii Doświadczalnej, Zakład Diagnostyki Hematologicznej, Instytut Hematologii i Transfuzjologii, ul. Indiry Gandhi 14, 02-776 Warszawa, e-mail: pjuszczynski@ihit.waw.pl 


\section{Wprowadzenie}

Badania translacyjne nad nowotworami układu chłonnego w perspektywie ostatnich 5 lat były wyjątkowo fascynującym i owocnym okresem. Przyczyniły się do tego nowe możliwości technologiczne umożliwiające wielkoprzepustowe sekwencjonowanie genomu i badanie mechanizmów epigenetycznych odpowiadających za jego funkcjonowanie, rozwój mocy obliczeniowych i bioinformatyki, a także zacieśniająca się współpraca ośrodków akademickich i przemysłu. Coraz większą złożonością charakteryzowały się modele eksperymentalne pozwalające na określenie wpływu mikrośrodowiska na wzrost nowotworów układu chłonnego. Zmiany te doprowadziły, z jednej strony, do lawinowej identyfikacji sprawczych zaburzeń genetycznych, a z drugiej - do masowego testowania małocząsteczkowych inhibitorów zmutowanych białek i badań biocząstek. $Z$ perspektywy ostatnich lat i wpływu tych badań na praktykę kliniczną za szczególnie ważne należy uznać te, które pozwoliły bliżej poznać epigenetyczne mechanizmy regulujące funkcjonowanie genomu i których translacyjny potencjał będzie najprawdopodobniej dalej rozwijany w kolejnych latach. Do rejestracji nowych, skutecznych według pierwszych doniesień, leków doprowadziły badania nad rolą sygnału receptora B-komórkowego (BCR, $B$-cell receptor), a badania nad rolą mikrośrodowiska i mechanizmów immunomodulacyjnych dotyczących nowotworu pozwalają wykorzystywać potencjał układu odpornościowego do walki z nowotworem.

\section{Mechanizmy epigenetyczne}

Opublikowanie pierwszego draftu genomu człowieka 15 lat temu otworzyło drogę do dalszych badań, których celem było poznanie mechanizmów jego funkcjonowania. Ostatnie 5 lat przyniosło znaczny postęp w zrozumieniu roli struktury chromatyny warunkującej dostępność DNA dla aparatu transkrypcyjnego. Kluczową rolę w tym procesie odgrywają modyfikacje epigenetyczne, w tym modyfikacje kowalencyjne białek histonowych, metylacja DNA oraz mechanizmy pozycjonowania nukleosomów [1]. Mechanizmy te wpływają na ekspresję genów poprzez utrzymanie otwartej, permisywnej struktury chromatyny dostępnej dla czynników transkrypcyjnych lub na jej upakowanie i transkrypcyjne wyciszenie. Modyfikacje epigenetyczne stanowiące sygnał dla aktywacji i represji mogą ze sobą współistnieć (chromatyna „dwuwartościowa” — bivalent marks), a usunięcie jednych lub drugich podczas różnicowania komórki decyduje o wyciszeniu lub aktywacji danego regionu chromatyny i losie komórki [2]. Modyfikacje epigenetyczne mają ponadto charakter hierarchiczny i kooperatywny, ostateczny efekt modyfikacji zależy zatem od całego szeregu wspólistniejących zmian.

Komórki nowotworowe wykazują wiele podobieństw - zarówno w zakresie aktywności kompleksów enzymatycznych odpowiedzialnych za modyfikacje epigenetyczne, jak i samych modyfikacji — do komórek macierzystych/progenitorowych [2]. Zaburzona regulacja epigenetyczna w komórkach nowotworowych może zatem warunkować ich podobieństwo do komórek macierzystych (stemness) i zwiększać potencjał ich odnawialności. Komórki nowotworowe wykazują ponadto różnice w stosunku do prawidłowych, zróżnicowanych komórek im odpowiadających, dotyczące modyfikacji epigenetycznych wyłączających ekspresję nowotworowych genów supresorowych oraz antygenów związanych $z$ nowotworem. Deregulacja epigenetyczna tych genów sprzyja zatem proliferacji i oporności na apoptozę oraz zmniejsza immunogenność komórek nowotworowych.

Enzymy warunkujące określone modyfikacje epigenetyczne mogą być również przedmiotem aberracji strukturalnych zmieniających ich aktywność. Mutacje w genach acetylotransferaz histonowych CREBBP (CREB binding protein) i EP300 (E1A binding protein p300) są częstym zjawiskiem - obserwowanym u 36\% chorych $z$ chłoniakiem rozlanym $z$ dużych komórek $B$ (DLBCL, diffuse large B-cell lymphoma) i $40 \%$ osób $z$ chłoniakiem grudkowym (FL, follicular lympho$m a)$ [3]. Mutacje te występowały w sposób wzajemnie się wykluczający i powodowały utratę funkcji kodowanych białek. Mutacje genu innego enzymu, EZH2 (enhancer of zeste 2, polycomb repressive complex 2 subunit), wykazującego katalityczną aktywność metylotransferazy lizyny K27 histonu H3, są częstym zaburzeniem w postaciach germinal center B-cell-like DLBCL (GCB-DLBCL) [4-7]. Mutacja dotycząca Tyr641 katalitycznej domeny SET genu EZH2 powoduje zwiększoną aktywność tego enzymu.

Niektóre zaburzenia $\mathrm{w}$ regulacji epigenetycznej w nowotworach układu chłonnego nie mają przyczyn strukturalnych. Redystrybucja i zaburzenia w metylacji DNA są typową cechą chłoniaków związanych $z$ centrum germinalnym, w tym DLBCL. Hipermetylacja i wyciszenie ekspresji genów w DLBCL różnicuje ich pochodzenie (GCB v. ABC [activated B-cell-like]) i stanowi czynnik prognostyczny [1]. 
Deregulowane mechanizmy epigenetyczne w nowotworach układu chłonnego stanowią obiecujący cel terapeutyczny. Celowana interwencja może dotyczyć acetylacji chromatyny, metylacji DNA lub swoiście deregulowanych enzymów, na przykład EZH2. Po rejestracji inhibitorów deacetylaz histonowych (HDAC, histone deacetylase inhibitors) w leczeniu chorych na T-komórkowe chłoniaki nie-Hodgkina (T-NHL, non-Hodgkin lymphoma) leki te trafiły do badań klinicznych w B-komórkowych NHL (B-NHL). Obecnie trwają badania $\mathrm{z}$ ich użyciem $\mathrm{w}$ monoterapii lub $\mathrm{w}$ połączeniu $z$ innymi lekami celowanymi lub konwencjonalną immunochemioterapią [8-10]. Na podobnym etapie badań w B-NHL są leki demetylujące. W badaniach przedklinicznych wykazano ponadto aktywność celowanych inhibitorów EZH2; inhibitor EPZ-6438, działający kompetycyjnie w stosunku do donora aktywnych grup metylowych S-adenozylometioniny, selektywnie hamuje metylację lizyny 27 histonu H3 (H3K27) zarówno w komórkach $z$ mutacją aktywująca EZH2 Y641, jak i jego dziką formą. Zahamowanie metylacji H3K27 prowadzi selektywnie do apoptozy komórek z mutacją aktywującą EZH2, co wskazuje na zależność komórek chłoniakowych od tej aberracji [11]. Inhibitor trafił do badań klinicznych 1. fazy w 2013 roku (NCT01897571).

Aby zaburzenia ilości, jakości i dystrybucji modyfikacji epigenetycznych DNA i białek histonowych przełożyły się na funkcjonowanie aparatu transkrypcyjnego, niezbędna jest obecność białek zdolnych do ich odczytania (chromatin readers). Białka te poprzez obecność swoistych domen wiążą się z modyfikacjami DNA i białek histonowych i rekrutują białka odpowiadające za transkrypcję. Do białek odczytujących ten kod histonowych modyfikacji epigenetycznych należą białka zawierające bromodomeny [12]. Spośród 46 znanych białek tej rodziny szczególnie interesująca $z$ punktu widzenia terapii celowanych jest podrodzina białek BET (bromodomain and extra-terminal domain BRD2, BRD3, BRD4). Białka te zawierają dwie bromodomeny na $\mathrm{N}$-końcu odpowiedzialne za wiązanie hiperacetylowanych regionów promotorowych i sekwencji wzmacniających. Poprzez C-końcową domenę białka BET rekrutują P-TEFb (positive transcription elongation factor), który fosforyluje polimerazę RNA II, co prowadzi do jej pełnej aktywacji [12]. Białka BET wiążą się preferencyjnie $z$ dużymi regionami chromatyny okupowanymi również przez białko MEDIATOR, zwanymi superenhancerami [13]; odpowiadają one za wzmocnienie ekspresji czynników transkrypcyjnych kluczowych dla ukierunkowania różnicowania komórek i odpo- wiadających za ich tożsamość, ale również za ekspresję onkogenów. Zahamowanie wiązania BRD4 do chromatyny powoduje toksyczność w modelach in vitro i in vivo $\mathrm{w}$ wielu nowotworach układu chłonnego [14-17]. W komórkach szpiczaka plazmocytowego (PCM, plasma cell myeloma) i chłoniaka Burkitta (BL, Burkitt lymphoma) inhibitory bromodomen powodują działanie cytostatyczne i cytotoksyczne w mechanizmie przynajmniej częściowo zależnym od zmian transkrypcji MYC (v-myc avian myelocytomatosis viral oncogene homolog) [17]. W DLBCL inhibitory BRD4 wykazywały cytostatyczny wpływ na szeroki panel linii komórkowych, niezależnie od ich charakterystyki molekularnej (ABC $v$. GCB) [14]. Inhibitory BRD4 wpływały głównie na zahamowanie cyklu komórkowego w DLBCL $\mathrm{i}$ istotnie ograniczały wzrost komórek ksenotransplantowanych immunoniekompetentnym myszom. Wykazano, że BRD4 wiąże się bardzo asymetrycznie do genomu DLBCL — około 33\% BRD4 lokalizowało się w obszarze 1,6\% superehancerów aktywnych genów [14]. Do białek regulowanych przez superenhancery w DLBCL należą liczne onkogeny, między innymi: BCL6 (B-cell CLL/lymphoma 6), OCA-B (POU2AF1, POU class 2 associating factor 1), PAX5 (paired box 5), IRF8 (interferon regulatory protein 8), MYC. Zahamowanie BRD4 ich swoistymi inhibitorami (JQ1) prowadziło do globalnego zmniejszenia transkrypcji zależnej od superenhancerów, a w szczególności zmniejszenia ekspresji onkogenów zależnych od tych sekwencji; BRD4 wiąże się na przykład silnie $z$ superenhancerami loci immunoglobulinowych, przez co inhibicja BRD4 zmniejsza ekspresję onkogenów translokowanych w obręb genów kodujących łańcuchy ciężkie immunoglobulin (IgH, immunoglobulin heavy chain) Reasumując, badania te wskazują, że BRD4 stanowi pomost między zaburzeniami epigenetycznymi a nadekspresją onkogenów w DLBCL, zahamowanie aktywności BRD4 w DLBCL prowadzi natomiast do uniwersalnego zmniejszenia ich ekspresji. Obserwacje te tłumaczą szerokie spektrum aktywności inhibitorów bromodomen w nowotworach układów chłonnego i krwiotwórczego. Wykazano również aktywność inhibitorów BRD4 w przedklinicznym modelu przewlekłej bialaczki limfocytowej (CLL, chronic lymphocytic leukemia) i w ostrej białaczce limfoblastycznej (ALL, acute lymphoblastic leukemia). Inhibitory bromodomen (JQ1, GSK525762, OTX015, CPI-0610) są aktualnie w trakcie badań klinicznych 1./2. fazy prowadzonych u chorych na różne nowotwory układów chłonnego, krwiotwórczego i narządów litych. 


\section{Sygnal BCR}

Aktywność BCR wyzwalana przez kontakt $z$ antygenem jest kluczowym mechanizmem warunkującym aktywację limfocytów i ich terminalne różnicowanie [18]. Ponadto BCR transmituje toniczne, niezależne od antygenu, sygnały działające antyapoptotycznie, a jego obecność na powierzchni naiwnych limfocytów B, limfocytów germinalnych i pamięci jest warunkiem podtrzymania ich populacji [18]. Patogenetyczną rolę sygnału BCR dla B-NHL udokumentowano w ostatnich 5 latach w wielu badaniach [19-21]. Komórkowe sygnały zależne od BCR wykazują cechy typowe dla aktywacji antygenem (sygnał przewlekle aktywny) lub mogą mieć charakter toniczny (niezależny od antygenu). W pierwszym przypadku nasilony sygnał BCR prowadzi do aktywacji czynnika transkrypcyjnego $\mathrm{NF} \kappa \mathrm{B}$ (nuclear factor of kappa light polypeptide gene enhancer in B-cells), a wyłączenie jego aktywności powoduje toksyczność w komórkach ABC-DLBCL. Do aktywacji sygnału BCR w tych komórkach zwykle prowadzą aberracje strukturalne dotyczące genów białek odpowiedzialnych za różne etapy przekazywania sygnałów od receptorów błonowych, a do najczęstszych należą mutacje $C D 79 B$, białek adaptorowych CARD11 (caspase recruitment domain family, member 11) i MYD88 (myeloid differentiation primary response 88 ), białek przekazujących sygnały TRAF2 (TNF receptor-associated factor 2 ), TRAF3, TRAF5, RANK (TNFRSF11a, tumor necrosis factor receptor superfamily, member 11a), TAK1 (MAP3K7, mitogen-activated protein kinase kinase kinase 7) i negatywnego regulatora szlaku - TNFAIP3 (tumor necrosis factor, alpha-induced protein 3) [22, 23]. Mechanizm wyzwalania sygnału „tonicznego” nie jest w pełni jasny; zahamowanie tego sygnału hamuje proliferację komórek DLBCL i indukuje ich apoptozę. Biochemicznie zahamowanie sygnału tonicznego poprzez wyłączenie aktywności kinazy SYK (spleen tyrosine kinase) prowadzi do zahamowania zależnych kaskad sygnałowych, skutkując obniżeniem stężenia jonów wapnia w przestrzeni wewnątrzkomórkowej, spadkiem aktywności AKT (v-akt murine thymoma viral oncogene homolog 1), ERK (MAPK1, mitogen-activated protein kinase 1) oraz ograniczeniem syntezy cholesterolu [24, 25]. Inaktywacja kinazy AKT prowadzi do zatrzymania cyklu komórkowego i indukcji apoptozy zależnej od nadekspresji proapoptotycznego białka rodziny BCL2, HRK (harakiri) [20].

Aktywność sygnału BCR odgrywa rolę patogenetyczną również w BL [26]. U myszy z równo- czesną nadekspresją Myc i konstytutywnie aktywną formą Pi3k (phosphatidylinositol-4,5-bisphosphate 3-kinase) chłoniaki rozwijały się szybciej niż $\mathrm{u}$ zwierząt $\mathrm{z}$ nadekspresją tylko Myc lub Pi3k. Co więcej, nowotwory powstające $\mathrm{w}$ tych podwójnie transgenicznych myszach są wierną fenokopią ludzkiego BL pod względem histologicznym, markerów powierzchniowych i profilu ekspresji białek [27]. Aktywacja szlaku PI3K jest również obserwowana w ludzkim BL, szczególnie w podtypie sporadycznym [26]. Głównym mechanizmem aktywującym ścieżkę PI3K są najprawdopodobniej mutacje aktywujące/zmieniające funkcję genu TCF3 (transcription factor 3 ) oraz mutacje utraty funkcji genu ID3 (inhibitor of DNA binding 3, dominant negative helix-loop-helix protein) będącego negatywnym regulatorem TCF3. Mutacje te są obserwowane w niemal $70 \%$ próbek pochodzących $z$ ludzkich sporadycznych BL [26]. W komórkach tego nowotworu TCF3 zwiększa ekspresję komponentów BCR oraz hamuje ekspresję fosfatazy SHP-1 (protein tyrosine phosphatase, non-receptor type 6) będącej inhibitorem sygnału BCR [26]. Obniżenie ekspresji czynnika TCF3 lub nadekspresja ID3 w liniach komórkowych BL zmniejszała toniczny sygnał BCR oraz poziom fosforylacji AKT [26].

Ze względu na istotną rolę patogenetyczną sygnału BCR w B-NHL, w tym w określonych podtypach molekularnych DLBCL, kaskady sygnałowe, które są aktywowane przez BCR, stanowią atrakcyjny cel interwencji terapeutycznej. Zależnie od strategii interwencji zahamowanie szlaku BCR może dotyczyć różnych kinaz. W ostatnich latach do badań przedklinicznych i klinicznych trafiły swoiste inhibitory, między innymi kinazy tyrozyny Brutona (BTK, Bruton tyrosine kinase), PI3K, mTOR (mechanistic target of rapamycin), AKT i MEK (MAP2K7, mitogen-activated protein kinase kinase 7). Znaczenie BTK dla rozwoju i funkcjonowania limfocytów B opisano po raz pierwszy w 1993 roku, gdy zidentyfikowano mutacje inaktywujące BTK jako przyczynę agammaglobulinemi Brutona [28-31]. Skutki wyłączenia BTK potwierdzono eksperymentalnie na modelach mysich pozbawionych tej kinazy, w których obserwowano zaburzenie rozwoju limfocytów B [32]. Kinaza BTK jest aktywowana w chłoniakach przez sygnał $z$ BCR i odgrywa kluczową rolę $\mathrm{w}$ transdukcji tego sygnału i aktywacji NFkB. Wyłączenie BTK metodami interferencji RNA jest toksyczne dla części linii komórkowych DLBCL $z$ wysoką spoczynkową aktywnością tego czynnika transkrypcyjnego [33]. Ponieważ mechanizm toksyczności inhibitorów BTK w chłoniakach DLBCL polega w głównej mierze na zahamowaniu 
kanonicznego szlaku aktywacji NFkB, oporność na inhibicję BTK może wynikać $z$ obecności mutacji uniezależniających aktywność $\mathrm{NFkB}$ od $\mathrm{BCR}$, na przykład mutacji aktywujących $C A R D 11$ lub mutacji aktywujących białko MYD88 (MYD88, myeloid differentiation primary response gene 88) (uczestniczące w alternatywnej aktywacji $\mathrm{NF} \kappa \mathrm{B}$ ) [34].

Selektywny inhibitor BTK — ibrutynib (PCI-32765) - zaprojektowano metodą analizy struktury białek oraz za pomocą narzędzi bioinformatycznych, takich jak SAR (structural-activity relationship), co umożliwiło opracowanie cząsteczek homologicznych do określonych domen BTK, spośród których wyselekcjonowano strukturę chemiczną ibrutynibu [35]. Inhibitor ten wiąże się kowalencyjnie $z$ cysteiną w pozycji 481 (Cys481) znajdującą się w pobliżu centrum aktywnego BTK [35]. Ibrutynib wykazuje wysoką aktywność w monoterapii u chorych na chłoniaka komórek płaszcza (MCL, mantle cell lymphoma) lub CLL i jest obecnie zarejestrowany do ich leczenia [36-38]. W badaniu klinicznym 1. fazy $z$ udziałem chorych na DLBCL [NCT00849654, ibrutynib spowodował częściową odpowiedź (PR, partial response) u 2 spośród 7 leczonych osób [36]. Lepsze wyniki raportowano $\mathrm{w}$ odniesieniu do DLBCL w badaniu klinicznym 2. fazy, w którym porównano odpowiedzi ABC-DLBCL w porównaniu z GCB-DLBCL. Wśród chorych na ABC-DLBCL odpowiedź uzyskano u 40\% leczonych osób, natomiast wśród chorych na GCB-DLBCL obiektywne odpowiedzi odnotowano jedynie u 1 z 19 leczonych [39]. Z powodu zróżnicowania odpowiedzi chłoniaków typu ABC-DLBCL i GCB-DLBCL w trwającym badaniu klinicznym 3. fazy, dotyczącym kombinacji ibrutynibu ze schematem R-CHOP (rytuksymab, cyklofosfamid, doksorubicyna, winkrystyna, prednizon), włączani są tylko chorzy na DLBCL $z$ podtypem innym niż GCB-DLBCL [NCT01855750]. Do innych inhibitorów BTK pozostających w badaniach klinicznych [NCT01659255, NCT01351935, NCT02031419] należą ONO-4059 oraz CC-292 (AVL-292) [40, 41].

Oś PI3K-AKT-mTOR kontroluje większość istotnych dla rozwoju nowotworu aspektów: przeżywalność, proliferację, metabolizm, migrację [42]. W wielu nowotworach ta oś sygnałowa jest aktywowana poprzez mutacje genów kodujących podjednostkę katalityczną PI3K (PIK3CA) lub negatywny regulator aktywności PI3K - PTEN (phosphatase and tensin homolog) [42]. W DLBCL aktywność osi PI3K-AKT-mTOR może zależeć od tych mechanizmów strukturalnych albo wiązać się z sygnałem BCR lub innych receptorów [43, 44]. Zahamowanie aktywności PI3K powoduje zmniej- szenie fosforylacji AKT i indukcję apoptozy części chłoniakowych linii komórkowych [45]. W lipcu 2014 roku amerykańska Agencja ds. Żywności i Leków (FDA, Food and Drug Administration) zarejestrowała inhibitor PI3K - idelalisib (CAL101, GS-1101), będący selektywnym inhibitorem $\mathrm{PI} 3 \mathrm{~K} \delta$, do stosowania u chorych na CLL/SLL (small lymphocytic lymphoma) i FL. W badaniach klinicznych PR na leczenie idelalisibem zaobserwowano u $62 \%$ pacjentów $z$ indolentnymi B-NHL, u $62 \%$ chorych na MCL i u żadnego z 9 leczonych z powodu DLBCL [46]. Połączenie idelalisibu $z$ rytuksymabem u chorych na CLL wiązało się z $81 \%$ odpowiedzi, w grupie chorych otrzymujących jedynie rytuksymab obserwowano $13 \%$ odpowiedzi [47, 48]; OS u chorych leczonych rytuksymabem w połączeniu $z$ idelalisibem po 12 miesiącach w tym badaniu wynosiło $92 \%$, a w grupie otrzymującej rytuksymab z placebo - 80\% [48]. Trwające badania kliniczne 2. fazy, między innymi w DLBCL, dotyczą łącznego stosowania inhibitora SYK (GS-9973) oraz idelalisibu [NCT01796470].

Poza inhibitorami PI3K selektywnymi wobec podjednostki p110 $\mathrm{w}$ badaniach klinicznych pozostaje również wiele inhibitorów PI3K hamujących wszystkie izoformy p110. Podstawą założenia o przewadze inhibitorów wszystkich podjednostek jest funkcjonalna kooperacja kilku podjednostek $\mathrm{w}$ transdukcji onkogennych sygnałów [42, 49]. Reprezentujący tę grupę buparlisib (BKM120) powodował apoptozę w liniach komórkowych BL, których przeżywalność zależy od tonicznego sygnału BCR [26]. Największym problemem związanym z pan-inhibitorami PI3K jest ich toksyczność [42].

Kinazę SYK zidentyfikowano jako cel terapeutyczny w wyniku prac nad rolą fosfatazy PTPROt (protein tyrosine phosphatase, receptor type, O, truncated) w biologii komórek B [25]. Nadekspresja fosfatazy PTPROt powodowała ograniczenie aktywności kinazy SYK oraz zmniejszoną proliferację $\mathrm{i}$ indukcję apoptozy $\mathrm{w}$ liniach komórkowych DLBCL [25]. Zgodnie $z$ tymi wynikami genetyczne lub farmakologiczne zahamowanie SYK w liniach komórkowych DLBCL zależnych od BCR prowadzi do zatrzymania cyklu komórkowego i masywnej apoptozy [50, 51]. Pierwszym inhibitorem SYK poddanym badaniom klinicznym był fostamatynib (R788) - prolek, który po podaniu doustnym jest metabolizowany do postaci aktywnej, tj. R406 [52]. $\mathrm{W}$ badaniach klinicznych 1 . i 2 . fazy z zastosowaniem R406 najwyższy odsetek odpowiedzi uzyskano u chorych na CLL/SLL (całkowity odsetek odpowiedzi [ORR, overall response rate] $55 \%$ ), a w przypadku DLBCL odsetek ten wynosił 
22\% [53]. Do nowszych inhibitorów SYK należą PRT060318, PRT062607 (P505-15) i GS-9973; PRT060318 i PRT062607 wykazywały aktywność w liniach komórkowych DLBCL, natomiast GS-9973 pozostaje w zaawansowanej fazie badań klinicznych [NCT01799889, NCT01796470] w nowotworach układów krwiotwórczego i chłonnego $[51,54]$.

\section{Rola mikrośrodowiska i związanych z nowotworem mechanizmów immunomodulacyjnych}

W badaniach $z$ ostatnich lat wykazano, że mikrośrodowisko nie jest jedynie biernym „podścieliskiem” dla komórek nowotworowych, ale stanowi ważny element struktury nowotworu wspierający proliferację komórek nowotworowych i działający antyapoptotycznie. Najbardziej jaskrawym przykładem powiązań między mikrośrodowiskiem a komórkami nowotworowymi jest klasyczny chłoniak Hodgkina (cHL, classical Hodgkin lympho$m a)$. Charakteryzuje się on obecnością nielicznych nowotworowych komórek Reed-Sternberga (R-S), otoczonych przez naciek limfocytów T, B, granulocytów, makrofagów, komórek plazmatycznych, eozynofilów, komórek tucznych i fibroblastów [55]. Szczególnymi cechami tego nacieku są jego immunosupresyjny charakter oraz złożona sieć bilateralnych powiązań między jej elementami i komórkami R-S. Komórki R-S, poprzez wydzielane chemokiny i cytokiny, indukują infiltrację innych komórek nacieku, które zwrotnie wspierają ich proliferację. Wydzielane przez komórki R-S białka immunomodulujące bezpośrednio wpływają na polaryzację nacieku T-komórkowego w kierunku immunosupresyjnych limfocytów Th2 i Treg i wyłączają skuteczną odpowiedź immunologiczną [55]. Do substancji immunomodulujących wydzielanych przez komórki R-S należą cytokiny profilu Th2, w tym interleukiny (IL [IL-4, IL-6, IL-13, IL-10]), chemokiny, czynnik wzrostu nowotworów $\beta$ (TGF- $\beta$, tumor grwoth factor $\beta$ ), galektyna 1 oraz ligandy receptora PD-1 (programmed death), PD-L1 i PD-L2 [55]. Wskutek wiązania obecnego na powierzchni limfocyta $T$ receptora PD-1 przez jeden $z$ jego ligandów receptor PD-1 rekrutuje fosfatazę SHP2 (PTPN11, protein tyrosine phosphatase, non-receptor type 11). Fosfataza ta defosforyluje białka kompleksu receptora T-komórkowego (CD3 $\delta$, ZAP70, PKC $\theta$ ), a w konsekwencji powoduje wyłączenie sygnału przekazywanego do wnętrza limfocyta przez ten receptor [56]; PD-L1 hamuje ponadto kostymulacyjny sygnał $z$ receptora
CD28 limfocyta T poprzez kompetycyjne wiązanie ligandu CD28, białka CD80 (B7-1) [56]. W konsekwencji tych zjawisk ekspresja PD-L1 prowadzi do zmniejszonej proliferacji w odpowiedzi na antygen, zmniejszonej produkcji interferonu gamma (IFN $\gamma$ ), zaburzeń degranulacji i obniżonej cytotoksyczności, określanych wspólnie jako zjawisko wyczerpania limfocytów T (T-cell exhaustion) [56]. Zjawisko to może w znacznym stopniu ograniczać skuteczność odpowiedzi immunologicznej gospodarza na obecność nowotworu. Nadekspresja PD-L1 w cHL wynika ze strukturalnej amplifikacji locus tego genu w obrębie regionu 9p24, obecnej zarówno w liniach komórkowych, jak i pierwotnych komórkach R-S [57]. Wskutek tej strukturalnej aberracji dochodzi również do koamplifikacji sąsiadującego $z$ PD-L1 genu kinazy JAK2 (Janus kinase 2). Aktywność tej kinazy dodatkowo wzmaga ekspresję PD-L1 poprzez fosforylację czynników transkrypcyjnych rodziny STAT (signal transducer and activator of transcription), wiążących się bezpośrednio w obrębie regionu promotorowego PD-L1 [57]. Limfocyty T nacieku komórkowego cHL wykazywały profil ekspresji genów charakterystyczny dla aktywacji receptora PD-1, a neutralizujące przeciwciała dla PD-1 przywracały prawidłową produkcję IFN $\gamma$ w tych komórkach [58]. Z badań tych wynika, $\dot{z}$ e blokada interakcji PD-1-PD-L1/PD-L2 może stanowić mechanizm wzmacniający T-zależną odpowiedź immunologiczną u chorych na cHL. Konsekwencją tych obserwacji były badania kliniczne 1. fazy u chorych na cHL $\mathrm{z}$ użyciem przeciwciał blokujących interakcję PD-1 i jego ligandów [59].

W pracy Ansell i wsp. [59] przedstawiono wyniki stosowania tego przeciwciała $\mathrm{w}$ grupie 23 chorych $z$ opornym na leczenie cHL lub jego nawrotem. Spośród badanych chorych, $87 \%$ przebyło przynajmniej 3 linie leczenia, $78 \%$ przebyło przeszczepienie autologicznych krwiotwórczych komórek macierzystych (auto-HSCT, autologous hematopoietic stem cell transplantation), a $78 \%$ otrzymywało wcześniej brentuksymab vedotin (BV). Interwencja polegała na podawaniu niwolumabu w dawce $3 \mathrm{mg} / \mathrm{kg} \mathrm{mc}$. co 2 tygodnie do progresji lub wystąpienia objawów toksyczności. W badaniu oceniono bezpieczeństwo stosowania niwolumabu, odpowiedź na leczenie i ekspresję potencjalnych biomarkerów (PD-L1 i STAT3). Działania niepożądane związane $z$ podawaniem leku wystąpiły u 78\% chorych (wysypka, małopłytkowość, biegunka, nudności, świąd, gorączka); działania niepożądane 3 . stopnia odnotowano u $22 \%$ chorych. Obiektywną odpowiedź na leczenie stwierdzono u 20 spośród 23 leczonych chorych (87\%), w tym 
u 4 chorych (17\%) uzyskano całkowitą remisję (CR), u 16 chorych (70\%) - PR, a u $3(13 \%)$ - stabilizację choroby. U 18 chorych, u których doszło do nawrotu po leczeniu BV, obiektywne odpowiedzi na leczenie dotyczyły 16 chorych (89\%), w tym jeden chory uzyskał CR (6\%), a $15(83 \%)$ - PR; PFS w 24. tygodniu badania oceniono u 11 chorych (12 chorych wyłączono $z$ badania $z$ powodu zakwalifikowania do auto-HSCT, objawów toksyczności lub progresji choroby) i wyniósł on $86 \%$. Mediana OS nie została osiągnięta. U 10 chorych, u których był dostępny materiał biopsyjny $z$ tkanki guza, przeprowadzono analizę metodą hybrydyzacji fluorescencyjnej in situ (FISH, fluorescence in situ hybrydization) locus PD-L1/PD-L2 (9p24), stwierdzając amplifikację (3-15 kopii) locus. U wszystkich chorych stwierdzono również wysoką ekspresję PD-L1/PD-L2 w komórkach R-S w badaniu immunohistochemicznym. W amplifikowanym locus 9p24 lokalizuje się również gen kinazy JAK2, której amplifikacje powodują aktywację czynników transkrypcyjnych STAT i dodatkowo wpływają na zwiększenie ekspresji PD-L1/PD-L2. Aktywność STAT3 obserwowano u wszystkich ocenionych chorych, co dowodzi, że zjawiska leżące u podłoża nadekspresji PD-L1/2 w cHL mogą stanowić klinicznie dostępny biomarker.

Wyniki badań ukierunkowanych na blokadę PD-1 z użyciem innego przeciwciała, pembrolizumabu, u chorych na cHL zaprezentowano na konferencji ASH (American Society of Hematology) w 2014 roku [60]. W badaniach tych potwierdzono również, że przeciwciała monoklonalne ukierunkowane na wyłączenie immunologicznego punktu kontrolnego PD-1/PD-L1/2 u chorych na cHL są stosunkowo dobrze tolerowane i wykazują aktywność kliniczną.

Punkt kontrolny PD-1/PD-L1/2 budzi duże zainteresowanie również $\mathrm{w}$ innych nowotworach układu chłonnego. Ekspresja ligandów tego układu dotyczy między innymi komórek CLL, FL i DLBCL o pierwotnej lokalizacji obejmującej jądra i ośrodkowy układ nerwowy (OUN). Zwłaszcza w przypadku tych ostatnich nowotworów - dotyczących tak zwanych miejsc uprzywilejowania immunologicznego (immune privilige sites) - terapeutyczne strategie immunomodulacyjne mogą być szczególnie uzasadnione. Wykazano, że u ponad $40 \%$ chorych $z$ pierwotnym chłoniakiem jądra występują amplifikacje 9p24 (PD-L1/2) [61]. Do nadekspresji ligandu PD-L2 może również prowadzić opisana po raz pierwszy translokacja t(3;9) TBL1XR1-PDL2. Skutkiem tej rearanżacji jest fizyczne zbliżenie regionu regulatorowe- go TBL1XR1 (chromosom 3) do 2 eksonu genu $P D C D 1 L G 2$, w którym jest zlokalizowany kodon start rozpoczynający translację pełnego białka PD-L2. Komórki $z$ tą translokacją charakteryzowały się szczególnie wysoką ekspresją powierzchniową PD-L2 [61]. W powyższych badaniach są identyfikowane mechanizmy sprzyjające immunologicznemu uprzywilejowaniu komórek chłoniakowych zlokalizowanych w ośrodkowym układzie nerwowym i jądrze, które mogą być celem interwencji terapeutycznej.

\section{Podsumowanie}

Ostatnie lata badań podstawowych i translacyjnych w onkohematologii, a szczególnie w nowotworach układu chłonnego, przyniosły wymierny, kliniczny i praktyczny wynik w postaci nie tylko nowych obserwacji dotyczących patogenezy chorób, ale także rejestracji nowych leków. Do największych wyzwań stojących przed badaczami należą dziś kwestie opracowania racjonalnych i klinicznie użytecznych biomarkerów umożliwiających identyfikację chorych, u których zastosowanie leku jest biologicznie uzasadnione. W odniesieniu do większości testowanych obecnie celów terapeutycznych i ich swoistych inhibitorów nie ma obecnie żadnego racjonalnego biomarkera, a zwłaszcza brakuje biomarkera „binarnego”, który pozwalałby w sposób jednoznaczny określić wskazania dla tych cząstek. W większości badań pojęcia „wysokiej” i „niskiej” ekspresji są arbitralne i niemożliwe do wystandaryzowania i zastosowania w praktyce klinicznej, a w szczególności w ramach badań klinicznych. Drugim wyzwaniem jest priorytetyzacja cząstek i logistyka badań klinicznych. Liczba powstających związków nie pozwala już dziś na testowanie każdego $z$ nich w warunkach badań klinicznych i zmusza do wyboru związków najbardziej obiecujących. Ostatnie $z$ wyzwań to opracowanie racjonalnych połączeń terapii celowanych, indywidualizacja terapii i poznanie interakcji między nowymi związkami.

\section{Piśmiennictwo}

1. Jiang Y., Hatzi K., Shaknovich R. Mechanisms of epigenetic deregulation in lymphoid neoplasms. Blood 2013; 121: 4271-4279.

2. Easwaran H., Tsai H.C., Baylin S.B. Cancer epigenetics: tumor heterogeneity, plasticity of stem-like states, and drug resistance. Mol. Cell 2014; 54: 716-727.

3. Pasqualucci L., Dominguez-Sola D., Chiarenza A. i wsp. Inactivating mutations of acetyltransferase genes in B-cell lymphoma. Nature 2011; 471: 189-195.

4. Yap D.B., Chu J., Berg T. i wsp. Somatic mutations at EZH2 Y641 act dominantly through a mechanism of selectively altered PRC2 catalytic activity, to increase H3K27 trimethylation. Blood 2011; 117: $2451-2459$. 
5. Bodor C., O'Riain C., Wrench D. i wsp. EZH2 Y641 mutations in follicular lymphoma. Leukemia 2011; 25: 726-729.

6. Morin R.D., Johnson N.A., Severson T.M. i wsp. Somatic mutations altering EZH2 (Tyr641) in follicular and diffuse large B-cell lymphomas of germinal-center origin. Nat. Genet. 2010; 42: 181-185.

7. Jiang Y., Melnick A. The epigenetic basis of diffuse large B-cell lymphoma. Semin. Hematol. 2015; 52: 86-96.

8. Watanabe T., Kato H., Kobayashi Y. i wsp. Potential efficacy of the oral histone deacetylase inhibitor vorinostat in a phase I trial in follicular and mantle cell lymphoma. Cancer Sci. 2010; 101: 196-200.

9. Amengual J.E., Clark-Garvey S., Kalac M. i wsp. Sirtuin and pan-class I/II deacetylase (DAC) inhibition is synergistic in preclinical models and clinical studies of lymphoma. Blood 2013; 122: 2104-2113.

10. Straus D.J., Hamlin P.A., Matasar M.J. i wsp. Phase I/II trial of vorinostat with rituximab, cyclophosphamide, etoposide and prednisone as palliative treatment for elderly patients with relapsed or refractory diffuse large B-cell lymphoma not eligible for autologous stem cell transplantation. Br. J. Haematol. 2015; 168: 663-670

11. Knutson S.K., Kawano S., Minoshima Y. i wsp. Selective inhibition of EZH2 by EPZ-6438 leads to potent antitumor activity in EZH2-mutant non-Hodgkin lymphoma. Mol. Cancer Ther. 2014; 13: 842-854.

12. Belkina A.C., Denis G.V. BET domain co-regulators in obesity, inflammation and cancer. Nat. Rev. Cancer 2012; 12: 465-477.

13. Loven J., Hoke H.A., Lin C.Y. i wsp. Selective inhibition of tumor oncogenes by disruption of super-enhancers. Cell 2013; 153: 320-334.

14. Chapuy B., McKeown M.R., Lin C.Y. i wsp. Discovery and characterization of super-enhancer-associated dependencies in diffuse large B cell lymphoma. Cancer Cell 2013; 24: 777-790.

15. Mertz J.A., Conery A.R., Bryant B.M. i wsp. Targeting MYC dependence in cancer by inhibiting BET bromodomains. Proc. Natl. Acad. Sci USA 2011; 108: 16669-16674.

16. Filippakopoulos P., Qi J., Picaud S. i wsp. Selective inhibition of BET bromodomains. Nature 2010; 468: 1067-1073.

17. Delmore J.E., Issa G.C., Lemieux M.E. i wsp. BET bromodomain inhibition as a therapeutic strategy to target c-Myc. Cell 2011; 146: 904-917.

18. Białopiotrowicz E., Warzocha K., Juszczyński P. Patogeneza nowotworów układu chłonnego. Hematologia 2013; 4: 321-332.

19. Niemann C.U., Wiestner A. B-cell receptor signaling as a driver of lymphoma development and evolution. Semin. Cancer Biol. 2013; 23: 410-421.

20. Chen L., Monti S., Juszczynski P. i wsp. SYK inhibition modulates distinct PI3K/AKT- dependent survival pathways and cholesterol biosynthesis in diffuse large B cell lymphomas. Cancer Cell 2013; 23: 826-838.

21. Young R.M., Staudt L.M. Targeting pathological B cell receptor signalling in lymphoid malignancies. Nat. Rev. Drug. Discov. 2013; 12: 229-243.

22. Compagno M., Lim W.K., Grunn A. i wsp. Mutations of multiple genes cause deregulation of NF-kappaB in diffuse large B-cell lymphoma. Nature 2009; 459: 717-721.

23. Pasqualucci L., Trifonov V., Fabbri G. i wsp. Analysis of the coding genome of diffuse large B-cell lymphoma. Nat. Genet. 2011; 43: 830-837.
24. Juszczynski P., Chen L., O‘Donnell E. i wsp. BCL6 modulates tonic BCR signaling in diffuse large B-cell lymphomas by repressing the SYK phosphatase, PTPROt. Blood 2009; 114: 5315-5321.

25. Chen L., Juszczynski P., Takeyama K., Aguiar R.C., Shipp M.A. Protein tyrosine phosphatase receptor-type O truncated (PTPROt) regulates SYK phosphorylation, proximal B-cell-receptor signaling, and cellular proliferation. Blood 2006; 108: 3428-3433.

26. Schmitz R., Young R.M., Ceribelli M. i wsp. Burkitt lymphoma pathogenesis and therapeutic targets from structural and functional genomics. Nature 2012; 490: 116-120.

27. Sander S., Calado D.P., Srinivasan L. i wsp. Synergy between PI3K signaling and MYC in Burkitt lymphomagenesis. Cancer Cell 2012; 22: 167-179.

28. Vetrie D., Vorechovsky I., Sideras P. i wsp. The gene involved in X-linked agammaglobulinaemia is a member of the Src family of protein-tyrosine kinases. 1993. J. Immunol. 2012; 188: 2948-2955.

29. Vetrie D., Vorechovsky I., Sideras P. i wsp. The gene involved in $\mathrm{X}$-linked agammaglobulinaemia is a member of the src family of protein-tyrosine kinases. Nature 1993; 361: 226-233.

30. Tsukada S., Saffran D.C., Rawlings D.J. i wsp. Deficient expression of a B cell cytoplasmic tyrosine kinase in human X-linked agammaglobulinemia. 1993. J. Immunol. 2012; 188: 2936-2947.

31. Tsukada S., Saffran D.C., Rawlings D.J. i wsp. Deficient expression of a B cell cytoplasmic tyrosine kinase in human X-linked agammaglobulinemia. Cell 1993; 72: 279-290.

32. Khan W.N., Alt F.W., Gerstein R.M. i wsp. Defective B cell development and function in Btk-deficient mice. Immunity 1995; 3: 283-299.

33. Davis R.E., Ngo V.N., Lenz G. i wsp. Chronic active B-cell-receptor signalling in diffuse large B-cell lymphoma. Nature 2010; 463: 88-92.

34. Ngo V.N., Young R.M., Schmitz R. i wsp. Oncogenically active MYD88 mutations in human lymphoma. Nature 2011; 470: 115-119.

35. Pan Z., Scheerens H., Li S.J. i wsp. Discovery of selective irreversible inhibitors for Bruton's tyrosine kinase. Chem. Med. Chem. 2007; 2: 58-61.

36. Advani R.H., Buggy J.J., Sharman J.P. i wsp. Bruton tyrosine kinase inhibitor ibrutinib (PCI-32765) has significant activity in patients with relapsed/refractory B-cell malignancies. J. Clin. Oncol. 2013; 31: 88-94.

37. Wang M.L., Rule S., Martin P. i wsp. Targeting BTK with ibrutinib in relapsed or refractory mantle-cell lymphoma. N. Engl. J. Med. 2013; 369: 507-516.

38. Byrd J.C., Furman R.R., Coutre S.E. i wsp. Targeting BTK with ibrutinib in relapsed chronic lymphocytic leukemia. N. Engl. J. Med. 2013; 369: 32-42.

39. Wilson W.H., Gerecitano J.F., Goy A. i wsp. The Bruton's tyrosine kinase (BTK) inhibitor, ibrutinib (PCI-32765), Has preferential activity in the abc subtype of relapsed/refractory de novo diffuse large B-cell lymphoma (DLBCL): interim results of a multicenter, open-label, phase 2 study. Blood 2012; 120: 686.

40. Harb W.A., Hill B.T., Gabrilove J. i wsp. Phase 1 study of single agent CC-292, a highly selective Bruton's tyrosine kinase (BTK) Inhibitor, in relapsed/refractory chronic lymphocytic leukemia (CLL). Blood 2013; 122: 1630-1630.

41. Yoshizawa T., Yasuhiro T., Honda H., Kawabata K. ONO-4059 a potent and selective reversible Bruton's tyrosine kinase (Btk) inhibitor: single agent, twice daily (BD) dosing and dosing with food results in sustained, high trough levels of ONO-4059, trans- 
lating into $100 \%$ tumour remission in a TMD-8 xenograft model. Blood 2014; 124: 4502.

42. Fruman D.A., Rommel C. PI3K and cancer: lessons, challenges and opportunities. Nat. Rev. Drug Discov. 2014; 13: 140-156.

43. Pfeifer M., Grau M., Lenze D. i wsp. PTEN loss defines a PI3K/ /AKT pathway-dependent germinal center subtype of diffuse large B-cell lymphoma. Proc. Natl. Acad. Sci. USA 2013; 110: 12420-12425.

44. Abubaker J., Bavi P.P., Al-Harbi S. i wsp. PIK3CA mutations are mutually exclusive with PTEN loss in diffuse large B-cell lymphoma. Leukemia 2007; 21: 2368-2370.

45. Lannutti B.J., Meadows S.A., Herman S.E. i wsp. CAL-101, a p110 delta selective phosphatidylinositol-3-kinase inhibitor for the treatment of B-cell malignancies, inhibits PI3K signaling and cellular viability. Blood 2011; 117: 591-594.

46. Kahl B., Byrd J.C., Flinn I.W. i wsp. Clinical safety and activity in a phase 1 study of CAL-101, an isoform-selective inhibitor of phosphatidylinositol 3-kinase p110\{delta\}, in patients with relapsed or refractory non-Hodgkin lymphoma. Blood 2010; 116: abstrakt 1777.

47. Gopal A.K., Kahl B.S., de Vos S. i wsp. PI3Kdelta inhibition by idelalisib in patients with relapsed indolent lymphoma. N. Engl. J. Med. 2014; 370: 1008-1018.

48. Furman R.R., Sharman J.P., Coutre S.E. i wsp. Idelalisib and rituximab in relapsed chronic lymphocytic leukemia. N. Engl. J. Med. 2014; 370: 997-1007.

49. Foukas L.C., Berenjeno I.M., Gray A., Khwaja A., Vanhaesebroeck B. Activity of any class IA PI3K isoform can sustain cell proliferation and survival. Proc. Natl. Acad. Sci. USA 2010; 107: 11381-11386.

50. Chen L., Monti S., Juszczynski P. i wsp. SYK-dependent tonic $\mathrm{B}$-cell receptor signaling is a rational treatment target in diffuse large B-cell lymphoma. Blood 2008; 111: 2230-2237.

51. Cheng S., Coffey G., Zhang X.H. i wsp. SYK inhibition and response prediction in diffuse large B-cell lymphoma. Blood 2011; 118: 6342-6352.

52. Braselmann S., Taylor V., Zhao H. i wsp. R406, an orally available spleen tyrosine kinase inhibitor blocks fc receptor signaling and reduces immune complex-mediated inflammation. J. Pharmacol. Exp. Ther. 2006; 319: 998-1008.

53. Friedberg J.W., Sharman J., Sweetenham J. i wsp. Inhibition of Syk with fostamatinib disodium has significant clinical activity in non-Hodgkin lymphoma and chronic lymphocytic leukemia. Blood 2010; 115: 2578-2585.

54. Spurgeon S.E., Coffey G., Fletcher L.B. i wsp. The selective SYK inhibitor P505-15 (PRT062607) inhibits B cell signaling and function in vitro and in vivo and augments the activity of fludarabine in chronic lymphocytic leukemia. J. Pharmacol. Exp. Ther. 2013; 344: 378-387.

55. Juszczyński P. Mikrośrodowisko komórek Reed-Sternberga w klasycznym chłoniaku Hodgkina - rola patogenetyczna i cel terapeutyczny. Hematologia 2011; 2: 1-14.

56. Keir M.E., Butte M.J., Freeman G.J.Sharpe A.H. PD-1 and its ligands in tolerance and immunity. Annu. Rev. Immunol. 2008; 26: 677-704.

57. Green M.R., Monti S., Rodig S.J. i wsp. Integrative analysis reveals selective 9p24.1 amplification, increased PD-1 ligand expression, and further induction via JAK2 in nodular sclerosing Hodgkin lymphoma and primary mediastinal large B-cell lymphoma. Blood 2010; 116: 3268-3277.

58. Chemnitz J.M., Eggle D., Driesen J. i wsp. RNA fingerprints provide direct evidence for the inhibitory role of TGFbeta and PD-1 on CD4 + T cells in Hodgkin lymphoma. Blood 2007; 110: 3226-3233.

59. Ansell S.M., Lesokhin A.M., Borrello I. i wsp. PD-1 blockade with nivolumab in relapsed or refractory Hodgkin's lymphoma. N. Engl. J. Med. 2015; 372: 311-319.

Moskowitz C.H., Ribrag V., Michot J.M. i wsp. D-1 Blockade with the monoclonal antibody pembrolizumab (MK-3475) in patients with classical Hodgkin lymphoma after brentuximab vedotin failure: preliminary results from a phase 1b study. Blood 2014; 124: abstrakt 290.

60. Chapuy B., Roemer M.G.M., Tan Y. i wsp. Actionable genetic features of primary testicular and primary central nervous system lymphomas. Blood 2014; 124: abstrakt 74. 